\title{
OWNERSHIP DOES MATTER IN THE FINANCIAL PERFORMANCE OF A BANKING UNDERTAKING: EVIDENCE FROM THE COMPARATIVE FINANCIAL PERFORMANCE OF PUBLIC SECTOR BANKS AND PRIVATE SECTOR BANKS IN INDIA
}

\author{
Parmil Kumar \\ Research Scholar, Dept. of Management Studies, M.M.U. Sadopur \& Associate Professor, \\ Commerce, Govt. PG College Ambala Cantt, India \\ Dr. Anupam Sharma \\ Associate Professor, Dept. of Management Studies, M.M.U. Sadopur, India
}

\begin{abstract}
A sharp focus is a must on the financial health of the banking institutions, any lapse in management of banks, not only shakes the trust of citizens but also threatens the entire financial system of the country. The present study uses a set of parametric and non-parametric techniques for analyzing and comparing the financial performance of the public sector banks(PSBs) and the private sector banks (PrSBs) in India from 200910 to $2018-19$.

In India, during the economic boom period, a large number of business projects had been financed or re-financed by the commercial banks especially by the public sector banks, which turned out to be non-viable in the current scenario or have more gestation period than expected, therefore a large part of loan assets of the banking sector has become non-performing, thereby having a significant impact on the profitability and financial health of these institutions. Moreover, the year 2018-19, is marked as a year of the 50th anniversary of bringing the banks under social control, so there is a need to evaluate the financial performance of these banks.
\end{abstract}

Key words: Public Sector Banks, Private Sector Banks, Interest income to Total Assets, Non-interest income to Total Assets, Return on Assets, Net NPA to Net Assets. 
Cite this Article: Parmil Kumar and Anupam Sharma, Ownership Does Matter in the Financial Performance of a Banking Undertaking: Evidence from the Comparative Financial Performance of Public Sector Banks and Private Sector Banks in India, International Journal of Management, 11(12), 2020, pp. 2730-2744.

http://iaeme.com/Home/issue/IJM?Volume=11\&Issue=12

\section{INTRODUCTION}

The economic development and prosperity of a country depend upon the efficiency and health of the financial sector of the economy. Commercial banks are an important player in the financial system as these act as intermediaries in mobilizing savings and allocating funds in the form of loans and advances for productive activities. Commercial bank attracts deposits from the general public and lends money for productive activities keeping an eye on risk as well as the profitability and the liquidity of its operation. Money flow in commercial banks depends upon the banking habits of the general public which in turn, depends on the trust of the general public in the financial health of these banks. Depositors keep their money parked in commercial banks if they are assured of the safety of their deposits and as well the interest income on their deposits. Therefore sound profitability and financial health of these entities is a must to build up the confidence of the depositors. The last some years have witnessed the increasing stressed assets, at an alarming rate, especially in public sector banks, forcing these banks for high provisioning for NPAs, which resulted in more pressure on the profitability of these banks. The impairment of assets of these banks not only adversely affected their earning capacity as well as affected the bank's capacity to lend. Earning is a must for survival and growth, otherwise, the existence of any enterprise will be threatened, therefore, to have sound financial health for a banking institution, profitability generation is a must.

In the last three decades, due to the deregulation of the banking industry In India, competition has become stiffer. Now in intermediation process commercial banks in India, comprising Public Sector Banks, Private Sector Banks, Regional Rural Banks, and Foreign Banks, not only has to compete with each other but also has to compete with the Non-Banking Financial Institutions, liberalized capital market and latest entered new digitally-focused financial companies, which has changed the way of doing the banking business. With the advancement of ICT, these digitally-focused new competitors are technologically more sound and capable of offering customer-centric new financial products and services more efficiently. In this competitive environment, the upper hand in profitability means less chance of failure, more internally generated funds for adaption of technology, expansion and growth, and more business for the bank.

Although the Reserve Bank of India (RBI) widely analyses data relating to the performance of commercial banks and keeps an eye on the performance of the financial sector including the banking sector, the inter-bank or inter-group financial performance of commercial banks is not done by the central bank.

Though a large number of studies on the measurement of profitability and financial performance of the banks in India had been done, among them major contribution made by Divatia and Venkachalam (1978), (Verghese (1983), Swami and Subrahmanyam (1993), Das (1999), Ram Mohan (2002). Bhayani (2006) and, Sangmi and Nazir (2010), but studies, which analyze the profitability of commercial banks in India post-2009 US financial crisis, posteffects of which have been emerging in India in the last some years, are rare. Moreover, the year 2018-19 is being celebrated as the $50^{\text {th }}$ anniversary of bringing the banks under social control, as in 1969, the Government of India nationalised 14 private sector banks having deposit base of more than 50 crores, to align the financial sector with the planning needs of the country, which paved way for the birth of public sector banks in India. So, it is the right time to assess 
the financial performance of these public sector banks, hence the present study analyzes and compares the financial performance of public sector banks and private sector banks in India from 2009-10 to 2018-19 using a set of parametric and non-parametric techniques.

\section{RESEARCH DESIGN}

The present study is based on secondary data of 39 Commercial Banks including 20 Public Sector Banks (PSBs) and 19 Private Sector Banks (PrSBs). Data of ten years from 2009-10 to 2018-19 collected from various published sources like RBI Publications, Indian Bank Association (IBA) Bulletins, and Annual Reports of the different banks. To analyze the financial performance of the banks the study has analyzed the following five parameters to arrive at composite financial performance score of banks:

- Interest income to Total Assets

- Non-interest income to Total Assets

- Return on Assets.

- Net NPAs to Net Assets, and

- Composite Financial Performance Score of banks

The study uses Average (A M), Standard Deviation (S.D), Ranking and Line Diagrams, etc. for analyzing the data. Arithmetic Mean and Standard Deviation (except for parameter 5) are calculated for each group of banks to test the hypothesis under parametric test, the t-test is used as a parametric test.

Ranks 1 to 39, are assigned to each bank on the bases of performance of the bank on a specific parameter as rank-1 is assigned for low NPAs or higher profitability and so on, than summed up separately for both types of bank groups, for testing the hypothesis, Mann-Whitney U-Test is used as a non-parametric test.

\section{Hypothesis of the Study}

Hypothesis 1: There is no significant difference between the PSBs and the PrSBs on interest incomes to total assets.

Hypothesis2: There is no significant difference between the PSBs and the PrSBs on noninterest incomes to total assets.

Hypothesis 3: There is no significant difference between the PSBs and the PrSBs on return on assets.

Hypothesis4: There is no significant difference between the PSBs and the PrSBs on Net NPA to Net Assets.

Hypothesis5 There is no significant difference between the PSBs and the PrSBs on the composite financial performance score of banks.

\section{DATA ANALYSIS AND INTERPRETATIONS}

\subsection{Parameter -1: Interest Income to Total Assets}

Interest income is the main source of income for a banking undertaking in any traditional banking model. The interest income to total assets shows the relationship between interest income and the total assets of a banking undertaking, the higher the ratio, the more the banking undertaking, will be safe and sound. An overview of Table 1 and Figure 1, depicts that both the banking groups have shown an increase in the interest income to total assets from 2009-10 to 2012-13 but from 2013-14 onwards, a pace of decline, in the interest income to total assets, set in for both the banking groups and in the year 2018-19, the interest income to total assets 
was well below the level it has in the year 2009-10 for both the banking groups. Column (7) of Table 1, showing the negative mean difference of interest income to total assets, indicates that the PrSBs consistently performed better, in interest income to total assets in all the years, than the PSBs. Column (8) of Table 2, showing the results of the t-test, indicates that there is a significant difference between the PSBs and PrSBs in interest income to total assets, similar results are advocated by Mann Whitney U-Test in Table 2 . Hence, hypothesis $\mathrm{H}_{1}$ is rejected and concluded that there is a significant difference in the interest income to total assets of both the banking groups.

Interest income to Total Assets of PSBs and PrSBs in India from 200910 to $2018-19$

12.00

10.00

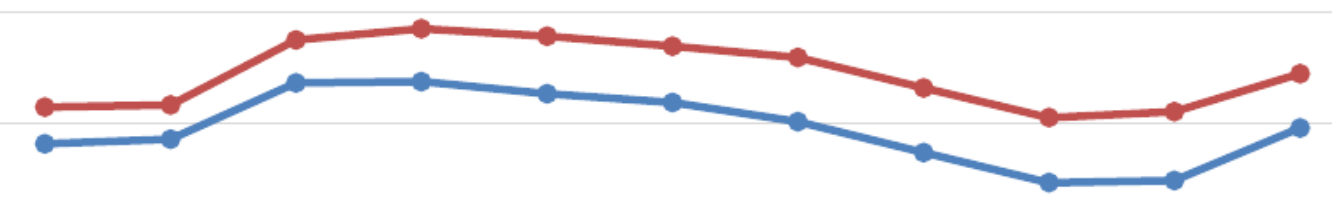

6.00

4.00

2.00

0.00

2009-10 2010-11 2011-12 2012-13 2013-14 2014-15 2015-16 2016-17 2017-18 2018-19 Avg.

$\rightarrow$ Public Sector Banks $\quad \longrightarrow$ Private Sector Banks

Figure 1

Table 1

\begin{tabular}{|c|c|c|c|c|c|c|c|}
\hline \multicolumn{8}{|c|}{ Interest Income to Total Assets of PSBs and PrSBs from 2009-10 to 2018-19 } \\
\hline \multicolumn{8}{|c|}{ (Results of Parametric T-Test) } \\
\hline \multirow[t]{2}{*}{$(1)$} & $(2)$ & (3) & (4) & $(5)$ & $(6)$ & (7) & $(8)$ \\
\hline & $\begin{array}{c}\text { Ownership } \\
\text { Group }\end{array}$ & $\mathrm{N}$ & Mean & $\begin{array}{c}\text { Std. } \\
\text { Deviation }\end{array}$ & $\begin{array}{l}\text { Std. Error } \\
\text { Mean }\end{array}$ & $\begin{array}{c}\text { Mean } \\
\text { Difference }\end{array}$ & t-value \\
\hline \multirow{2}{*}{$2009-10$} & PSB & 20 & 7.62 & 0.425 & 0.095 & \multirow{2}{*}{-0.667} & \multirow{2}{*}{$-3.205^{*}$} \\
\hline & PrSB & 19 & 8.287 & 0.823 & 0.189 & & \\
\hline \multirow{2}{*}{$2010-11$} & PSB & 20 & 7.708 & 0.392 & 0.088 & \multirow{2}{*}{-0.617} & \multirow{2}{*}{$-3.245^{*}$} \\
\hline & PrSB & 19 & 8.325 & 0.75 & 0.172 & & \\
\hline \multirow{2}{*}{ 2011-12 } & PSB & 20 & 8.726 & 0.544 & 0.122 & \multirow{2}{*}{-0.776} & \multirow{2}{*}{$-3.549 *$} \\
\hline & PrSB & 19 & 9.502 & 0.803 & 0.184 & & \\
\hline \multirow{2}{*}{$2012-13$} & PSB & 20 & 8.749 & 0.593 & 0.133 & \multirow{2}{*}{-0.955} & \multirow{2}{*}{$-4.118^{*}$} \\
\hline & PrSB & 19 & 9.703 & 0.84 & 0.193 & & \\
\hline 2013-14 & PSB & 20 & 8.524 & 0.664 & 0.148 & -1.043 & $-4.408 *$ \\
\hline
\end{tabular}


Ownership Does Matter in the Financial Performance of a Banking Undertaking: Evidence from the Comparative Financial Performance of Public Sector Banks and Private Sector Banks in India

\begin{tabular}{|c|c|c|c|c|c|c|c|}
\hline & PrSB & 19 & 9.567 & 0.811 & 0.186 & & \\
\hline \multirow{2}{*}{$2014-15$} & PSB & 20 & 8.369 & 0.684 & 0.153 & \multirow{2}{*}{-1.019} & \multirow{2}{*}{$-4.75^{*}$} \\
\hline & PrSB & 19 & 9.388 & 0.654 & 0.15 & & \\
\hline \multirow{2}{*}{$2015-16$} & PSB & 20 & 8.022 & 0.653 & 0.146 & \multirow{2}{*}{-1.16} & \multirow{2}{*}{$-5.22 *$} \\
\hline & PrSB & 19 & 9.182 & 0.735 & 0.169 & & \\
\hline \multirow{2}{*}{ 2016-17 } & PSB & 20 & 7.464 & 0.598 & 0.134 & \multirow{2}{*}{-1.169} & \multirow{2}{*}{$-6.187^{*}$} \\
\hline & PrSB & 19 & 8.632 & 0.581 & 0.133 & & \\
\hline \multirow{2}{*}{ 2017-18 } & PSB & 20 & 6.918 & 0.538 & 0.12 & \multirow{2}{*}{-1.176} & \multirow{2}{*}{$-6.434^{*}$} \\
\hline & PrSB & 19 & 8.093 & 0.602 & 0.138 & & \\
\hline \multirow{2}{*}{ 2018-19 } & PSB & 20 & 6.959 & 0.504 & 0.113 & \multirow{2}{*}{-1.241} & \multirow{2}{*}{$-7.177 *$} \\
\hline & PrSB & 19 & 8.2 & 0.575 & 0.132 & & \\
\hline \multirow{2}{*}{$\begin{array}{c}\text { Average } \\
\text { Interest } \\
\text { Income to } \\
\text { Total } \\
\text { Assets }\end{array}$} & PSB & 20 & 7.906 & 0.482 & 0.108 & \multirow[b]{2}{*}{-0.982} & \multirow[b]{2}{*}{$-5.466^{*}$} \\
\hline & PrSB & 19 & 8.888 & 0.634 & 0.145 & & \\
\hline
\end{tabular}

Table 2

\begin{tabular}{|c|c|c|c|c|c|c|c|c|c|c|c|}
\hline \multicolumn{12}{|c|}{ Interest Income to Total Assets of PSBs and PrSBs from 2009-10 to 2018-19 } \\
\hline \multicolumn{12}{|c|}{ (Results of Non-parametric Test) } \\
\hline & $\begin{array}{c}2009- \\
10\end{array}$ & $\begin{array}{c}2010- \\
11\end{array}$ & $\begin{array}{c}2011- \\
12\end{array}$ & $\begin{array}{c}2012- \\
13\end{array}$ & $\begin{array}{c}2013- \\
14\end{array}$ & $\begin{array}{l}2014- \\
15\end{array}$ & $\begin{array}{c}2015- \\
16\end{array}$ & $\begin{array}{c}2016- \\
17\end{array}$ & $\begin{array}{c}2017- \\
18\end{array}$ & $\begin{array}{c}2018- \\
19\end{array}$ & $\begin{array}{l}\text { Average } \\
\text { Interest } \\
\text { Income } \\
\text { to Total } \\
\text { Assets }\end{array}$ \\
\hline $\begin{array}{l}\text { Mann- } \\
\text { Whitney } \\
\text { U }\end{array}$ & 95 & 78 & 73 & 61 & 55 & 47.5 & 39.5 & 27.5 & 26 & 23 & 37 \\
\hline $\begin{array}{l}\text { Wilcoxon } \\
\text { W }\end{array}$ & 305 & 288 & 283 & 271 & 265 & 257.5 & 249.5 & 237.5 & 236 & 233 & 247 \\
\hline Z & $2.67 *$ & $3.15^{*}$ & $3.29 *$ & $3.63 *$ & $3.79 *$ & $4.00^{-}$ & $4.23 *$ & $4.57^{-}$ & $4.61^{-}$ & $4.69 *$ & $-4.299 *$ \\
\hline
\end{tabular}

\subsection{Parameter -2: Non-interest income to Total Assets}

Non-interest income mainly consists of fee-based income, which is another important source of income of a banking undertaking. A large number of empirical studies have indicated that the banks are moving towards fee-based income due to declining margins as a result of increased competition after the deregulation of the banking industry in India. Table 3 and Figure 2 , indicates that the highest non-interest income to total assets reported 1.101 by the PSBs and 1.500 that of the PrSBs in the year 2016-17. The PSBs have reported the lowest non-interest income to total assets $0.7745 \%$ in the year 2015-16, while that for the PrSBs is $1.213 \%$ in the year 2018-19. The ten-year average of non-interest income to total assets of the PSBs is $0.892 \%$ and that of the PrSBs is $1.310 \%$. Column (7) of Table 3 , showing the negative mean difference of non-interest income to total assets, indicates that the PrSBs consistently performed better in 
non-interest income to total assets, in all the years than the PSBs. The mean difference of noninterest income to total assets is found lowest at $0.291 \%$ in the year $2017-18$ and it is the highest at $0.552 \%$ in the year 2014-15. Column (8) of Table 3, showing the results of the t-test, indicates that there is a significant difference in net interest income to total assets of the PSBs and that of the PrSBs, in all the years. In Table 4, the results of Mann Whitney U-Test, as the computed z-value is significant in all the years, advocates similar results. The average noninterest to total assets of the banks differ significantly. Hypothesis $\mathrm{H}_{2}$ is rejected and concluded that the non-interest income to total assets of the PSBs and the PrSBs differs significantly.

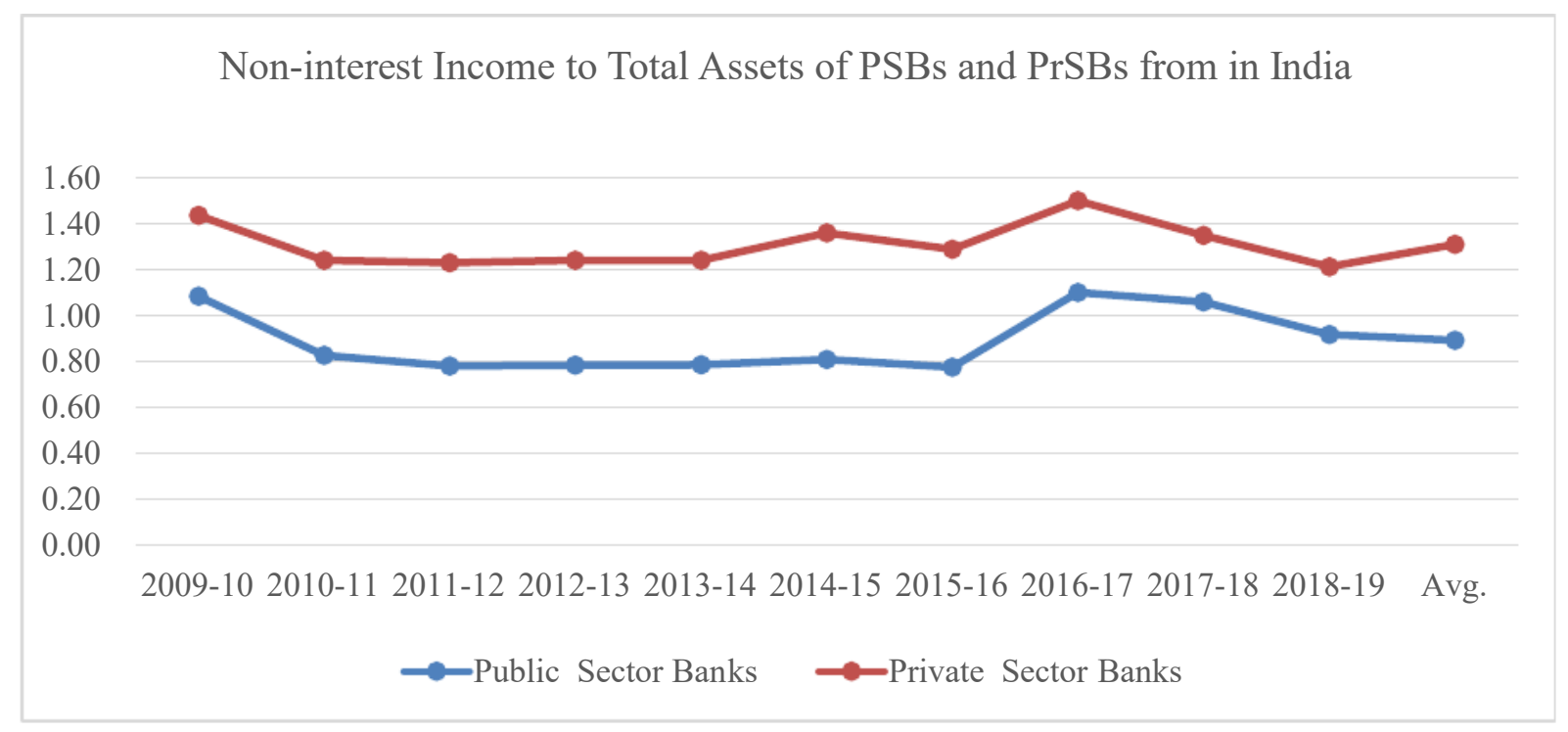

Figure 2

Table 3

\begin{tabular}{|c|c|c|c|c|c|c|c|}
\hline \multicolumn{8}{|c|}{ Non-interest Income to Total Assets of PSBs and PrSBs from 2009-10 to 2018-19 } \\
\hline \multicolumn{8}{|c|}{ (Results of Parametric T-Test) } \\
\hline \multirow[t]{2}{*}{ (1) } & (2) & (3) & (4) & $(5)$ & (6) & (7) & $(8)$ \\
\hline & $\begin{array}{c}\text { Ownership } \\
\text { Group }\end{array}$ & $\mathrm{N}$ & Mean & $\begin{array}{c}\text { Std. } \\
\text { Deviation }\end{array}$ & $\begin{array}{l}\text { Std. Error } \\
\text { Mean }\end{array}$ & $\begin{array}{c}\text { Mean } \\
\text { Difference }\end{array}$ & t-value \\
\hline \multirow{2}{*}{$2009-10$} & PSB & 20 & 1.084 & 0.208 & 0.047 & \multirow{2}{*}{-0.353} & \multirow{2}{*}{$-2.981^{*}$} \\
\hline & PrSB & 19 & 1.437 & 0.485 & 0.111 & & \\
\hline \multirow{2}{*}{ 2010-11 } & PSB & 20 & 0.826 & 0.147 & 0.033 & \multirow{2}{*}{-0.415} & \multirow{2}{*}{$-3.756^{*}$} \\
\hline & PrSB & 19 & 1.241 & 0.47 & 0.108 & & \\
\hline \multirow{2}{*}{ 2011-12 } & PSB & 20 & 0.78 & 0.135 & 0.03 & \multirow{2}{*}{-0.451} & \multirow{2}{*}{$-4.337 *$} \\
\hline & PrSB & 19 & 1.231 & 0.444 & 0.102 & & \\
\hline \multirow{2}{*}{$2012-13$} & PSB & 20 & 0.782 & 0.154 & 0.034 & \multirow{2}{*}{-0.458} & \multirow{2}{*}{$-4.385^{*}$} \\
\hline & PrSB & 19 & 1.24 & 0.44 & 0.101 & & \\
\hline \multirow{2}{*}{ 2013-14 } & PSB & 20 & 0.786 & 0.146 & 0.033 & \multirow{2}{*}{-0.455} & \multirow{2}{*}{$-3.594 *$} \\
\hline & PrSB & 19 & 1.24 & 0.546 & 0.125 & & \\
\hline \multirow{2}{*}{ 2014-15 } & PSB & 20 & 0.809 & 0.221 & 0.049 & \multirow{2}{*}{-0.552} & \multirow{2}{*}{$-4.222 *$} \\
\hline & PrSB & 19 & 1.361 & 0.539 & 0.124 & & \\
\hline $2015-16$ & PSB & 20 & 0.774 & 0.167 & 0.037 & -0.514 & $-3.802^{*}$ \\
\hline
\end{tabular}


Ownership Does Matter in the Financial Performance of a Banking Undertaking: Evidence from the Comparative Financial Performance of Public Sector Banks and Private Sector Banks in India

\begin{tabular}{|c|c|c|c|c|c|c|c|}
\hline & $\operatorname{PrSB}$ & 19 & 1.288 & 0.581 & 0.133 & & \\
\hline \multirow{2}{*}{ 2016-17 } & PSB & 20 & 1.101 & 0.212 & 0.047 & \multirow{2}{*}{-0.398} & \multirow{2}{*}{$-2.937^{*}$} \\
\hline & PrSB & 19 & 1.5 & 0.567 & 0.13 & & \\
\hline \multirow{2}{*}{$2017-18$} & PSB & 20 & 1.059 & 0.329 & 0.074 & \multirow{2}{*}{-0.291} & \multirow{2}{*}{$-2.059 *$} \\
\hline & $\operatorname{PrSB}$ & 19 & 1.35 & 0.535 & 0.123 & & \\
\hline \multirow{2}{*}{ 2018-19 } & PSB & 20 & 0.916 & 0.276 & 0.062 & \multirow{2}{*}{-0.297} & \multirow{2}{*}{$-2.279 *$} \\
\hline & PrSB & 19 & 1.213 & 0.51 & 0.117 & & \\
\hline \multirow{2}{*}{$\begin{array}{l}\text { Average } \\
\text { Non- } \\
\text { Interest } \\
\text { Income to } \\
\text { Total } \\
\text { Assets }\end{array}$} & PSB & 20 & 0.892 & 0.148 & 0.033 & \multirow[b]{2}{*}{-0.418} & \multirow[b]{2}{*}{$-3.812 *$} \\
\hline & $\operatorname{PrSB}$ & 19 & 1.31 & 0.467 & 0.107 & & \\
\hline
\end{tabular}

Table 4

\begin{tabular}{|c|c|c|c|c|c|c|c|c|c|c|c|}
\hline \multicolumn{12}{|c|}{ Non-interest Income to Total Assets of PSBs and PrSBs from 2009-10 to 2018-19 } \\
\hline \multicolumn{12}{|c|}{ (Results of Non-parametric Test) } \\
\hline & $\begin{array}{c}2009- \\
10\end{array}$ & $\begin{array}{c}2010- \\
11\end{array}$ & $\begin{array}{c}2011- \\
12\end{array}$ & $\begin{array}{c}2012- \\
13\end{array}$ & $\begin{array}{c}2013- \\
14\end{array}$ & $\begin{array}{l}2014- \\
15\end{array}$ & $\begin{array}{c}2015- \\
16\end{array}$ & $\begin{array}{c}2016- \\
17\end{array}$ & $\begin{array}{c}2017- \\
18\end{array}$ & $\begin{array}{c}2018- \\
19\end{array}$ & $\begin{array}{l}\text { Average } \\
\text { Non- } \\
\text { Interest } \\
\text { Income } \\
\text { to Total } \\
\text { Assets }\end{array}$ \\
\hline $\begin{array}{l}\text { Mann- } \\
\text { Whitney } \\
\text { U }\end{array}$ & 106 & 77 & 62 & 65.5 & 89 & 61 & 79 & 100.5 & 133.5 & 117 & 81 \\
\hline $\begin{array}{l}\text { Wilcoxon } \\
\text { W }\end{array}$ & 316 & 287 & 272 & 275.5 & 299 & 271 & 289 & 310.5 & 343.5 & 327 & 291 \\
\hline $\mathrm{Z}$ & $2.36^{*}$ & $3.18^{*}$ & $3.58 *$ & $3.48 *$ & $2.84 *$ & $3.63^{-}$ & $3.12 *$ & $2.52 *$ & 1.587 & $2.05 *$ & $-3.063^{*}$ \\
\hline
\end{tabular}

\subsection{Parameter -3: Return on Assets}

Return on assets is a widely used parameter to measure the performance of an enterprise, a high return on assets is the indicator of the sound earning capacity of the enterprise. It indicates the relationship between earnings and assets of the enterprise. Table 5 and Figure 3, indicate that the return on assets of both the banking group has been showing a falling trend, while the falling trend set in for the PSBs in the year 2010-11 onwards and that for the PrSBs in the year 201213 onwards. The PSBs have reported the highest return on assets 0.796 in the year 2010-11, since then, return on assets of these banks have shown a falling trend and even become negative from 2015-16 onwards, these banks have reported the lowest return on assets -(01.620) in the year 2018-19. The return of assets of the PrSBs has shown a rising trend from 2009-10 to 201213, when these banks reported the highest return on assets 1.294, since then, the return on assets of these banks also have shown a falling trend and reported lowest at 0.565 in the year 2018 19. The average return on assets reported by the PSBs is 0.091 and that of the PrSBs is 1.003 . 
Column (7) of Table 5, showing the negative mean difference of the return on assets of the PSBs and that of the PrSBs, indicates that the PrSBs consistently performed better than the PSBs in return on assets, in all the years. The mean difference of return on assets is found lowest at $0.81 \%$ in the year $2009-10$ and since then it has been showing a rising trend, except for the year 2016-17, when the mean difference of return on assets, has shown a small improvement from the previous figure. The mean difference of return on assets is the highest at $2.185 \%$ in the year 2018-19. Column (8) of Table 5, showing the results of the t-test, indicates that there is a significant difference in the return on assets of the PSBs and that of the PrSBs, from the year 2011-12 onwards, as well as in the ten year's average of the return on assets. The same results are advocated by the Mann Whitney U-Test in Table 6, as the computed z-value is significant in all these years as well as of the ten-years average of the return on assets. Hypothesis $\mathrm{H}_{3}$ is rejected and concluded that the return on assets of the PSBs and that of the PrSBs differs significantly.

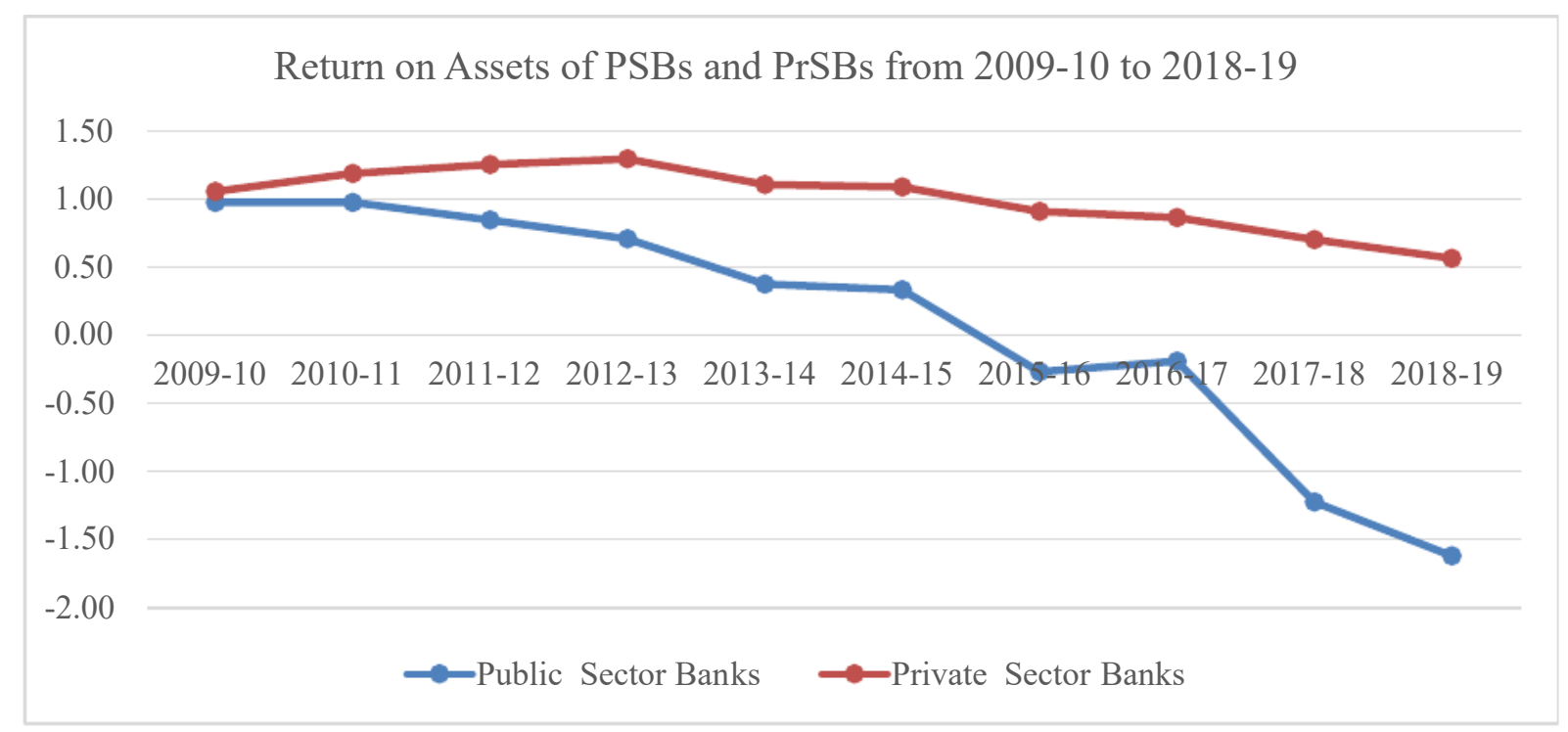

Figure 3

Table 5

\begin{tabular}{|c|c|c|c|c|c|c|c|}
\hline \multicolumn{8}{|c|}{ Return on Assets of Public Sector Banks and Private Sector Banks from 2009-10 to 2018-19 } \\
\hline \multicolumn{8}{|c|}{ Results of Parametric T-Test } \\
\hline \multirow[t]{2}{*}{1} & 2 & 3 & 4 & 5 & 6 & 7 & 8 \\
\hline & $\begin{array}{l}\text { Ownership } \\
\text { Group }\end{array}$ & $\mathrm{N}$ & Mean & $\begin{array}{c}\text { Std. } \\
\text { Deviation }\end{array}$ & $\begin{array}{l}\text { Std. Error } \\
\text { Mean }\end{array}$ & $\begin{array}{c}\text { Mean } \\
\text { Difference }\end{array}$ & t-value \\
\hline \multirow{2}{*}{$2009-10$} & PSB & 20 & 0.975 & 0.352 & 0.079 & \multirow{2}{*}{-0.081} & \multirow{2}{*}{-0.425} \\
\hline & $\operatorname{PrSB}$ & 19 & 1.056 & 0.775 & 0.178 & & \\
\hline \multirow{2}{*}{ 2010-11 } & PSB & 20 & 0.976 & 0.307 & 0.069 & \multirow{2}{*}{-0.211} & \multirow{2}{*}{-1.481} \\
\hline & PrSB & 19 & 1.186 & 0.553 & 0.127 & & \\
\hline \multirow{2}{*}{ 2011-12 } & PSB & 20 & 0.845 & 0.277 & 0.062 & \multirow{2}{*}{-0.409} & \multirow{2}{*}{$-2.546^{*}$} \\
\hline & PrSB & 19 & 1.253 & 0.659 & 0.151 & & \\
\hline \multirow{2}{*}{$2012-13$} & PSB & 20 & 0.708 & 0.244 & 0.055 & \multirow{2}{*}{-0.586} & \multirow{2}{*}{$-4.328 *$} \\
\hline & PrSB & 19 & 1.294 & 0.551 & 0.127 & & \\
\hline 2013-14 & PSB & 20 & 0.376 & 0.42 & 0.094 & -0.732 & $-3.315^{*}$ \\
\hline
\end{tabular}


Ownership Does Matter in the Financial Performance of a Banking Undertaking: Evidence from the Comparative Financial Performance of Public Sector Banks and Private Sector Banks in India

\begin{tabular}{|c|c|c|c|c|c|c|c|}
\hline & PrSB & 19 & 1.107 & 0.889 & 0.204 & & \\
\hline \multirow{2}{*}{$2014-15$} & PSB & 20 & 0.334 & 0.179 & 0.04 & \multirow{2}{*}{-0.755} & \multirow{2}{*}{$-3.606^{*}$} \\
\hline & PrSB & 19 & 1.089 & 0.919 & 0.211 & & \\
\hline \multirow{2}{*}{ 2015-16 } & PSB & 20 & -0.269 & 0.594 & 0.133 & \multirow{2}{*}{-1.178} & \multirow{2}{*}{$-4.861 *$} \\
\hline & PrSB & 19 & 0.91 & 0.896 & 0.206 & & \\
\hline \multirow{2}{*}{$2016-17$} & PSB & 20 & -0.191 & 0.574 & 0.128 & \multirow{2}{*}{-1.056} & \multirow{2}{*}{$-4.423 *$} \\
\hline & PrSB & 19 & 0.865 & 0.891 & 0.204 & & \\
\hline \multirow{2}{*}{$2017-18$} & PSB & 20 & -1.224 & 0.832 & 0.186 & \multirow{2}{*}{-1.925} & \multirow{2}{*}{$-6.917^{*}$} \\
\hline & PrSB & 19 & 0.701 & 0.906 & 0.208 & & \\
\hline \multirow{2}{*}{ 2018-19 } & PSB & 20 & -1.62 & 1.583 & 0.354 & \multirow{2}{*}{-2.185} & \multirow{2}{*}{$-5.145^{*}$} \\
\hline & PrSB & 19 & 0.565 & 0.982 & 0.225 & & \\
\hline \multirow{2}{*}{$\begin{array}{l}\text { Average } \\
\text { Return } \\
\text { on } \\
\text { Assets }\end{array}$} & PSB & 20 & 0.091 & 0.365 & 0.082 & \multirow[b]{2}{*}{-0.192} & \multirow[b]{2}{*}{$-5.452 *$} \\
\hline & PrSB & 19 & 1.003 & 0.648 & 0.149 & & \\
\hline
\end{tabular}

Table 6

\begin{tabular}{|c|c|c|c|c|c|c|c|c|c|c|c|}
\hline \multicolumn{12}{|c|}{ Return on Assets of Public Sector Banks and Private Sector Banks from 2009-10 to 2018-19 } \\
\hline \multicolumn{12}{|c|}{ Results of Non-parametric Test } \\
\hline & $\begin{array}{c}2009 \\
-10\end{array}$ & $\begin{array}{l}2010 \\
-11\end{array}$ & $\begin{array}{l}2011 \\
-12\end{array}$ & $\begin{array}{l}2012 \\
-13\end{array}$ & $\begin{array}{l}2013 \\
-14\end{array}$ & $\begin{array}{l}2014 \\
-15\end{array}$ & $\begin{array}{l}2015 \\
-16\end{array}$ & $\begin{array}{l}2016 \\
-17\end{array}$ & $\begin{array}{c}2017 \\
-18\end{array}$ & $\begin{array}{l}2018 \\
-19\end{array}$ & $\begin{array}{c}\text { Averag } \\
\mathrm{e} \\
\text { Return } \\
\text { on } \\
\text { Assets }\end{array}$ \\
\hline $\begin{array}{l}\text { Mann- } \\
\text { Whitney } \\
\text { U }\end{array}$ & 146 & $\begin{array}{r}123 . \\
5\end{array}$ & 80 & 61 & 57.5 & 41 & 42 & 43 & 23.5 & 25 & 50 \\
\hline $\begin{array}{l}\text { Wilcoxo } \\
\mathrm{n} \mathrm{W}\end{array}$ & 356 & $\begin{array}{r}333 . \\
5 \\
\end{array}$ & 290 & 271 & $\begin{array}{r}267 . \\
5 \\
\end{array}$ & 251 & 252 & 253 & $\begin{array}{r}233 . \\
5\end{array}$ & 235 & 260 \\
\hline $\mathrm{Z}$ & -1.24 & -1.87 & $\begin{array}{r}- \\
3.09 \\
*\end{array}$ & $\begin{array}{r}- \\
3.63 \\
*\end{array}$ & $\begin{array}{r}- \\
3.72 \\
*\end{array}$ & $\begin{array}{r}- \\
4.19 \\
*\end{array}$ & $\begin{array}{r}- \\
4.16 \\
*\end{array}$ & $\begin{array}{r}- \\
4.13 \\
*\end{array}$ & $\begin{array}{r}- \\
4.68 \\
*\end{array}$ & $\begin{array}{r}- \\
4.64 \\
*\end{array}$ & $-3.934 *$ \\
\hline
\end{tabular}

\subsection{Parameter -4: Net NPA to Net Assets}

Net NPA to net assets is a widely used parameter to measure the quality of the asset of a banking undertaking, a low net NPA to net assets is the indicator of sound assets quality of a banking undertaking. It indicates the relationship between the net non-performing assets and the net assets of a banking undertaking. Table 7 and Figure 4, indicate that though the net NPA to net assets of the PSBs was lower than that of the PrSBs in the year 2009-10, this ratio has been showing a rising trend for the PSBs, even has increased at an alarming rate from the year 201415 onwards and the ratio becomes the worst at $9.85 \%$ in the year 2017-18. The net NPA to net assets of the PrSBs has fallen, nearly by $46 \% \%$ over its previous value, in the year 2010-10, thereafter it has been also showing a rising trend but rise was not as sharp as was in the case of the PSBs. The PSBs have the highest net NPA to net assets $9.85 \%$ in the year $2017-18$ and the 
PrSBs have the highest net NPA to net assets $2.67 \%$ in the year 2018-19. The PSBs have the lowest net NPA to net assets $0.987 \%$ in the year 2009-10 and the PrSBs have the lowest net NPA to net assets $0.58 \%$ in the year 2010-11. The ten-years average of the net NPA to net assets of the PSBs is $4.289 \%$ and that of the PrSBs is $1.479 \%$.

Column (7) of Table 7, showing the negative mean difference of the net NPA to net assets, indicates that the PrSBs consistently performed better than the PSBs in the net NPA to net Assets, except in all the year 2009-10. The mean difference of net NPA to net assets is found lowest at 0.11 in the year 2009-10 and since then it has been showing a rising trend till the year 2018-18. The mean difference of net NPA to net assets is the highest $7.33 \%$ in the year 201718. Column (8) of Table 7, showing the results of the t-test, indicates that there is a significant difference in the net NPA to net assets of the PSBs and that of the PrSBs, from the year 201011 onwards, as well as in the ten year's average of the net NPA to net assets. The same results are advocated by the Mann Whitney U-Test in Table 8, as the computed z-value is significant in all these years as well as of the ten-years average of the net NPA to net assets. Hypothesis $\mathrm{H}_{4}$ is rejected and concluded that the net NPA to net assets of the PSBs and that of the PrSBs differs significantly.

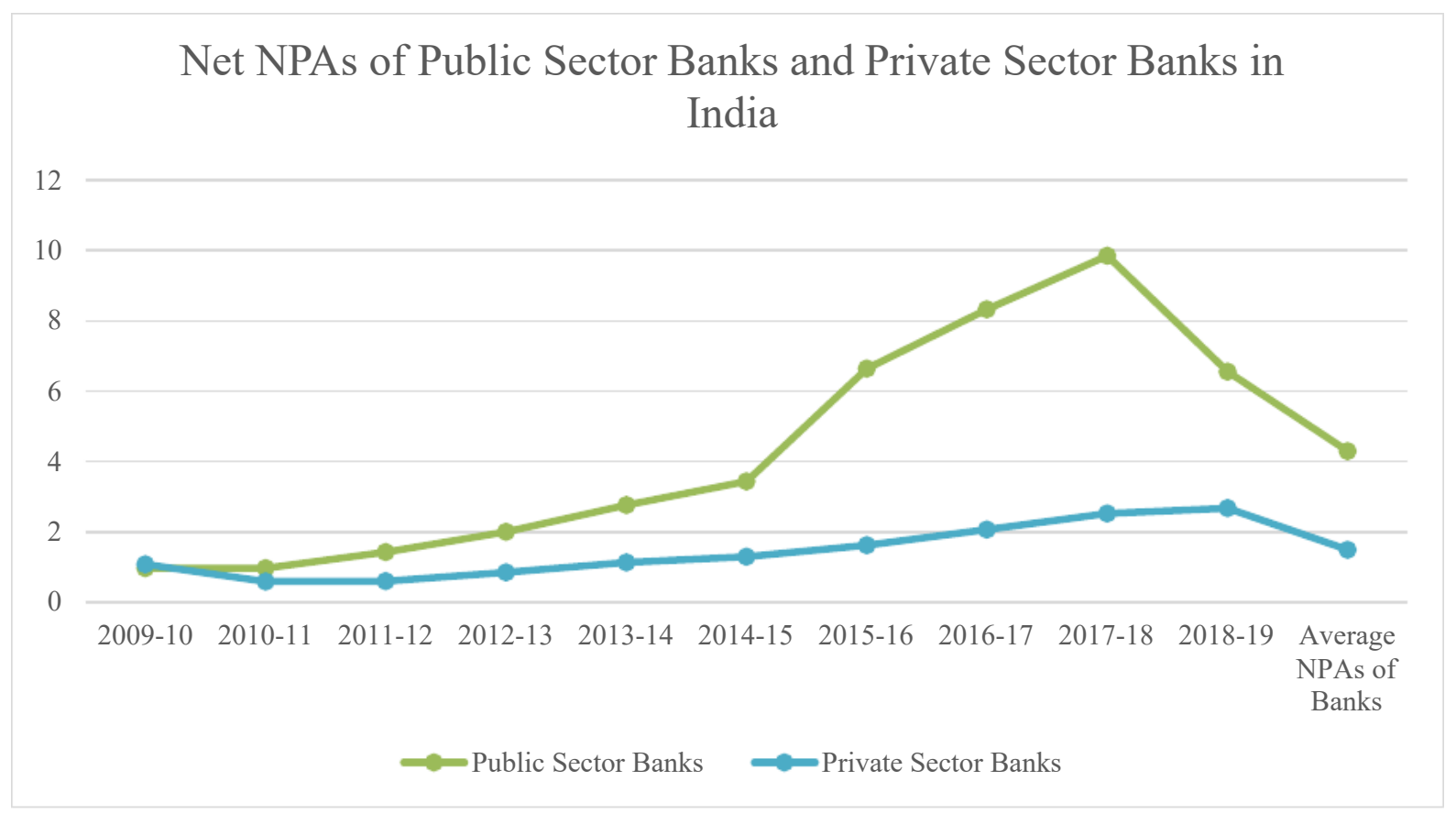

Figure 4

Table 7

\begin{tabular}{|c|c|c|c|c|c|c|c|}
\hline \multicolumn{8}{|c|}{$\begin{array}{l}\text { Net NPAs to Net Assets of Public Sector Banks and Private Sector Banks from 2009- } \\
110 \text { to 2018-19 }\end{array}$} \\
\hline \multicolumn{8}{|c|}{ Results of Parametric T-Test } \\
\hline 1 & 2 & 3 & 4 & 5 & 6 & 7 & 8 \\
\hline & $\begin{array}{l}\text { Ownership } \\
\text { Type }\end{array}$ & $\mathrm{N}$ & Mean & $\begin{array}{c}\text { Std. } \\
\text { Deviation }\end{array}$ & $\begin{array}{c}\text { Std. } \\
\text { Error } \\
\text { Mean }\end{array}$ & $\begin{array}{c}\text { Mean } \\
\text { Difference }\end{array}$ & t-value \\
\hline \multirow{2}{*}{$2009-10$} & PSB & 20 & 0.961 & 0.599 & 0.134 & \multirow{2}{*}{-0.108} & \multirow{2}{*}{-0.381} \\
\hline & PrSB & 18 & 1.069 & 1.105 & 0.26 & & \\
\hline \multirow{2}{*}{$2010-11$} & PSB & 20 & 0.965 & 0.402 & 0.09 & \multirow{2}{*}{0.384} & \multirow{2}{*}{$2.608^{*}$} \\
\hline & PrSB & 18 & 0.581 & 0.504 & 0.119 & & \\
\hline
\end{tabular}


Ownership Does Matter in the Financial Performance of a Banking Undertaking: Evidence from the Comparative Financial Performance of Public Sector Banks and Private Sector Banks in India

\begin{tabular}{|c|c|c|c|c|c|c|c|}
\hline \multirow{2}{*}{$2011-12$} & PSB & 20 & 1.422 & 0.577 & 0.129 & \multirow{2}{*}{0.829} & \multirow{2}{*}{$4.523 *$} \\
\hline & PrSB & 18 & 0.593 & 0.55 & 0.13 & & \\
\hline \multirow{2}{*}{$2012-13$} & PSB & 20 & 2.000 & 0.769 & 0.172 & \multirow{2}{*}{1.159} & \multirow{2}{*}{$4.403 *$} \\
\hline & PrSB & 18 & 0.841 & 0.854 & 0.201 & & \\
\hline \multirow{2}{*}{ 2013-14 } & PSB & 20 & 2.759 & 1.263 & 0.282 & \multirow{2}{*}{1.629} & \multirow{2}{*}{$4.256^{*}$} \\
\hline & PrSB & 18 & 1.129 & 1.076 & 0.254 & & \\
\hline \multirow{2}{*}{$2014-15$} & PSB & 20 & 3.429 & 1.142 & 0.255 & \multirow{2}{*}{2.144} & \multirow{2}{*}{$5.914^{*}$} \\
\hline & PrSB & 18 & 1.285 & 1.086 & 0.256 & & \\
\hline \multirow{2}{*}{$2015-16$} & PSB & 20 & 6.635 & 1.946 & 0.435 & \multirow{2}{*}{5.023} & \multirow{2}{*}{$9.419 *$} \\
\hline & PrSB & 19 & 1.612 & 1.303 & 0.299 & & \\
\hline \multirow{2}{*}{ 2016-17 } & PSB & 20 & 8.318 & 2.765 & 0.618 & \multirow{2}{*}{6.253} & \multirow{2}{*}{$8.595^{*}$} \\
\hline & PrSB & 19 & 2.065 & 1.592 & 0.365 & & \\
\hline \multirow{2}{*}{$2017-18$} & PSB & 20 & 9.845 & 3.755 & 0.84 & \multirow{2}{*}{7.332} & \multirow{2}{*}{$7.732 *$} \\
\hline & PrSB & 19 & 2.512 & 1.769 & 0.406 & & \\
\hline \multirow{2}{*}{ 2018-19 } & PSB & 20 & 6.555 & 2.136 & 0.478 & \multirow{2}{*}{3.89} & \multirow{2}{*}{$6.016^{*}$} \\
\hline & PrSB & 19 & 2.665 & 1.886 & 0.433 & & \\
\hline \multirow{2}{*}{$\begin{array}{c}\text { Average NPAs to } \\
\text { Net Assets of Banks }\end{array}$} & PSB & 20 & 4.289 & 1.243 & 0.278 & \multirow{2}{*}{2.81} & \multirow{2}{*}{$8.184 *$} \\
\hline & PrSB & 19 & 1.479 & 0.854 & 0.196 & & \\
\hline
\end{tabular}

Table 8

\begin{tabular}{|c|c|c|c|c|c|c|c|c|c|c|c|}
\hline \multicolumn{12}{|c|}{$\begin{array}{l}\text { Net NPAs of Public Sector Banks and Private Sector Banks from 2009-10 to 2018-19 } \\
\text { Results of Non-parametric Test }\end{array}$} \\
\hline & $\begin{array}{c}2009 \\
-10\end{array}$ & $\begin{array}{c}2010 \\
-11\end{array}$ & $\begin{array}{l}2011 \\
-12\end{array}$ & $\begin{array}{l}2012 \\
-13\end{array}$ & $\begin{array}{l}2013 \\
-14\end{array}$ & $\begin{array}{l}2014 \\
-15\end{array}$ & $\begin{array}{l}2015 \\
-16\end{array}$ & $\begin{array}{l}2016 \\
-17\end{array}$ & $\begin{array}{c}2017 \\
-18\end{array}$ & $\begin{array}{l}2018 \\
-19\end{array}$ & $\begin{array}{c}\text { Avg. } \\
\text { NPAs } \\
\text { of } \\
\text { Bank } \\
\text { s }\end{array}$ \\
\hline $\begin{array}{l}\text { Mann- } \\
\text { Whitney } \\
\text { U }\end{array}$ & 162.5 & 83 & 46 & 52 & 44 & 32 & 2 & 11 & 10 & 31 & 7 \\
\hline $\begin{array}{l}\text { Wilcoxo } \\
\mathrm{n} \text { W }\end{array}$ & 333.5 & 254 & 217 & 223 & 215 & 203 & 192 & 201 & 200 & 221 & 197 \\
\hline Z & 0.513 & $2.84^{-}$ & $3.92 *$ & $3.74 *$ & $3.98 *$ & $4.33^{-}$ & $5.28^{-}$ & $5.03 *$ & $5.06^{*}$ & $4.47^{-}$ & $5.14^{*}$ \\
\hline
\end{tabular}

\subsection{Parameter -5: Composite Financial Performance Score of Banks}

The composite financial performance score of banks is calculated by clubbing the performance of the banks on four parameters i.e. interest income to total assets, non-interest income to total assets, return on assets, and net NPA to net assets. To arrive at ranking on the composite financial performance score, ranks are assigned to the banks based on the rank's total achieved by the bank on the clubbed performance on above mentioned four parameters. The average ranks are assigned for having the same rank's total. Here, a non-parametric test (Mann Whitney U-Test) is being used to analyze and compare the banks on the composite financial performance score. 
As per ranking in Table 9, with rank's total 581 of the PSBs and 199 that of the PrSBs, the PrSBs having higher ranking positions has performed better than the PSBs. Table 10, exhibits the results of Mann Whitney U-test, as the computed z-value 5.086, higher than the corresponding tabulated value 1.96 at $5 \%$ level of significance, is significant. Hypothesis 5 is rejected and concluded that the composite financial performance scores differ significantly in both the bank groups.

Table 9

\begin{tabular}{|c|c|c|c|c|c|c|}
\hline \multicolumn{7}{|c|}{ Composite Financial Performance Score of Public Sector Banks and Private Sector Banks } \\
\hline Parameters & 1 & 2 & 3 & 4 & & 5 \\
\hline Name of the Parameter & $\begin{array}{l}\text { Interest } \\
\text { Income } \\
\text { to Total } \\
\text { Assets }\end{array}$ & $\begin{array}{l}\text { Non- } \\
\text { interest } \\
\text { income } \\
\text { to Total } \\
\text { Assets }\end{array}$ & $\begin{array}{l}\text { Return } \\
\text { on } \\
\text { Assets }\end{array}$ & $\begin{array}{c}\text { Net } \\
\text { NPAs of } \\
\text { Banks }\end{array}$ & $\begin{array}{c}\text { Rank's } \\
\text { Total }\end{array}$ & $\begin{array}{c}\text { Composite } \\
\text { Financial } \\
\text { Performance } \\
\text { Score of } \\
\text { Banks }\end{array}$ \\
\hline & Rank & Rank & Rank & Rank & Total & Rank \\
\hline $\begin{array}{l}\text { ALLAHABAD BANK } \\
\text { (PSB) }\end{array}$ & 25 & 22 & 30 & 30 & 107 & 30 \\
\hline ANDHRA BANK (PSB) & 14 & 25 & 21 & 25 & 85 & 19 \\
\hline $\begin{array}{l}\text { BANK OF BARODA } \\
\text { (PSB) }\end{array}$ & 39 & 28 & 18 & 18 & 103 & 26 \\
\hline BANK OF INDIA (PSB) & 38 & 27 & 25 & 28 & 118 & 34 \\
\hline $\begin{array}{l}\text { BANK OF } \\
\text { MAHARASHTRA (PSB) }\end{array}$ & 24 & 31 & 32 & 32 & 119 & 35 \\
\hline CANARA BANK (PSB) & 30 & 19 & 19 & 24 & 92 & 21 \\
\hline $\begin{array}{l}\text { CENTRAL BANK OF } \\
\text { INDIA (PSB) }\end{array}$ & 26 & 35 & 35 & 35 & 131 & 37.5 \\
\hline $\begin{array}{l}\text { CORPORATION BANK } \\
\text { (PSB) }\end{array}$ & 27 & 21 & 29 & 29 & 106 & 28.5 \\
\hline DENA BANK (PSB) & 28 & 32 & 37 & 34 & 131 & 37.5 \\
\hline $\begin{array}{l}\text { IDBI BANK LIMITED } \\
\text { (PSB) }\end{array}$ & 34 & 15 & 39 & 37 & 125 & 36 \\
\hline INDIAN BANK (PSB) & 22 & 23 & 13 & 19 & 77 & 16 \\
\hline $\begin{array}{l}\text { INDIAN OVERSEAS } \\
\text { BANK (PSB) }\end{array}$ & 23 & 17 & 36 & 39 & 115 & 32 \\
\hline $\begin{array}{l}\text { ORIENTAL BANK OF } \\
\text { COMMERCE (PSB) }\end{array}$ & 20 & 24 & 27 & 31 & 102 & 25 \\
\hline $\begin{array}{l}\text { PUNJAB AND SIND } \\
\text { BANK (PSB) }\end{array}$ & 17 & 38 & 23 & 27 & 105 & 27 \\
\hline $\begin{array}{l}\text { PUNJAB NATIONAL } \\
\text { BANK (PSB) }\end{array}$ & 33 & 16 & 24 & 33 & 106 & 28.5 \\
\hline $\begin{array}{l}\text { SYNDICATE BANK } \\
\text { (PSB) }\end{array}$ & 32 & 33 & 26 & 22 & 113 & 31 \\
\hline UCO BANK (PSB) & 35 & 37 & 33 & 36 & 141 & 39 \\
\hline $\begin{array}{l}\text { UNION BANK OF } \\
\text { INDIA (PSB) }\end{array}$ & 29 & 20 & 20 & 26 & 95 & 22 \\
\hline $\begin{array}{l}\text { UNITED BANK OF } \\
\text { INDIA (PSB) }\end{array}$ & 36 & 12 & 31 & 38 & 117 & 33 \\
\hline VIJAYA BANK (PSB) & 21 & 34 & 22 & 20 & 97 & 23 \\
\hline Rank's Total of PSBs & 553 & 509 & 540 & 583 & 2185 & 581 \\
\hline
\end{tabular}


Ownership Does Matter in the Financial Performance of a Banking Undertaking: Evidence from the Comparative Financial Performance of Public Sector Banks and Private Sector Banks in India

\begin{tabular}{|c|c|c|c|c|c|c|}
\hline $\begin{array}{l}\text { AXIS BANK LIMITED } \\
\text { (PrSB) }\end{array}$ & 31 & 2 & 7 & 9 & 49 & 11 \\
\hline $\begin{array}{l}\text { CATHOLIC SYRIAN } \\
\text { BANK LTD (PrSB) }\end{array}$ & 7 & 26 & 34 & 21 & 88 & 20 \\
\hline $\begin{array}{l}\text { CITY UNION BANK } \\
\text { LIMITED (PrSB) }\end{array}$ & 1 & 8 & 5 & 10 & 24 & 5 \\
\hline $\begin{array}{l}\text { DCB BANK LIMITED } \\
\text { (PrSB) }\end{array}$ & 8 & 9 & 15 & 7 & 39 & 8 \\
\hline $\begin{array}{l}\text { FEDERAL BANK LTD } \\
\text { (PrSB) }\end{array}$ & 11 & 18 & 11 & 6 & 46 & 10 \\
\hline $\begin{array}{l}\text { HDFC BANK LTD. } \\
(\operatorname{PrSB})\end{array}$ & 13 & 5 & 1 & 1 & 20 & 3 \\
\hline $\begin{array}{l}\text { ICICI BANK LIMITED } \\
(\mathrm{PrSB})\end{array}$ & 37 & 3 & 6 & 17 & 63 & 13.5 \\
\hline $\begin{array}{l}\text { INDUSIND BANK LTD } \\
(\mathrm{PrSB})\end{array}$ & 5 & 1 & 3 & 3 & 12 & 1 \\
\hline $\begin{array}{l}\text { JAMMU \& KASHMIR } \\
\text { BANK LTD (PrSB) }\end{array}$ & 18 & 36 & 16 & 14 & 84 & 18 \\
\hline $\begin{array}{l}\text { KARNATAKA BANK } \\
\text { LTD (PrSB) }\end{array}$ & 12 & 11 & 17 & 13 & 53 & 12 \\
\hline $\begin{array}{l}\text { KARUR VYSYA BANK } \\
\text { LTD (PrSB) }\end{array}$ & 4 & 10 & 10 & 12 & 36 & 7 \\
\hline $\begin{array}{l}\text { KOTAK MAHINDRA } \\
\text { BANK LTD. (PrSB) }\end{array}$ & 2 & 4 & 2 & 5 & 13 & 2 \\
\hline $\begin{array}{l}\text { LAKSHMI VILAS } \\
\text { BANK LTD (PrSB) }\end{array}$ & 6 & 14 & 28 & 23 & 71 & 15 \\
\hline $\begin{array}{l}\text { NAINITAL BANK LTD } \\
(\mathrm{PrSB})\end{array}$ & 16 & 39 & 9 & 15 & 79 & 17 \\
\hline $\begin{array}{l}\text { RBL BANK LIMITED } \\
(\operatorname{PrSB})\end{array}$ & 19 & 7 & 12 & 4 & 42 & 9 \\
\hline $\begin{array}{l}\text { SOUTH INDIAN BANK } \\
\text { LTD (PrSB) }\end{array}$ & 9 & 29 & 14 & 11 & 63 & 13.5 \\
\hline $\begin{array}{l}\text { TAMILNAD } \\
\text { MERCANTILE BANK } \\
\text { LTD (PrSB) }\end{array}$ & 3 & 13 & 8 & 8 & 32 & 6 \\
\hline $\begin{array}{l}\text { THE DHANALAKSHMI } \\
\text { BANK LTD (PrSB) }\end{array}$ & 15 & 30 & 38 & 16 & 99 & 24 \\
\hline YES BANK LTD. (PrSB) & 10 & 6 & 4 & 2 & 22 & 4 \\
\hline Rank's Total of PrSBs & 227 & 271 & 240 & 197 & 935 & 199 \\
\hline
\end{tabular}

Table 10

\begin{tabular}{|l|c|l|c|}
\hline \multicolumn{2}{|c|}{$\begin{array}{r}\text { Composite Financial Performance Score of Public Sector Banks and Private Sector Banks } \\
\text { Results of Non-parametric T-Test }\end{array}$} \\
\hline Public Sector Banks & Value & Private Sector Banks & Value \\
\hline Rank's Total & $\mathbf{5 8 1}$ & Rank's Total & 199 \\
\hline $\mathrm{n} 1$ & 20 & n2 & 19 \\
\hline U1 & 9 & U2 & 371 \\
\hline Computed Z-value & -5.086 & & \\
\hline * INDICATES VALUE IS SIGNIFICANT & \\
\hline
\end{tabular}




\section{SUMMARY AND CONCLUSIONS}

On the parameter interest income to total assets, there is a significant difference between the public sector banks and the private sector banks in all the years. On the ten year's average of the interest income to total assets, the private sector banks performed better than the public sector banks, as per raking in Table 9, the top thirteen ranking positions from $1^{\text {st }}$ to $13^{\text {th }}$ are occupied by the private sector banks and last thirteen ranking positions i.e. $28^{\text {th }}$ to $39^{\text {th }}$ are occupied by the public sector banks.

On the parameter non-interest income to total assets, there is a significant difference between the public sector banks and the private sector banks in all the years as well as in ten year's average of the non-interest income to total assets. On ten year's average of the net interest income to total assets, the private sector banks perform better than the public sector banks, as per raking in Table 9, the top eleven ranking positions i.e. $1^{\text {st }}$ to $11^{\text {th }}$ are occupied by the private sector banks.

On the parameter return on assets, there is a significant difference between the public sector banks and the private sector banks in all the years except in the year 2009-10 and 2010-11. On ten year's average of the return on assets, the private sector banks perform better than the public sector banks, as per raking in Table 9, the top twelve ranking positions from $1^{\text {st }}$ to $12^{\text {th }}$ are occupied by the private sector banks.

On parameter composite financial performance score of banks, there is a significant difference between the public sector banks and the private sector banks. The private sector banks perform better than the public sector banks, as per raking in Table 9, the top thirteen ranking positions i.e. $1^{\text {st }}$ to $13^{\text {th }}$ are occupied by the private sector banks.

An overview of the data analysis shows that the PrSBs performed better on all the parameters of the financial performance of a bank i.e. interest income to total assets, noninterest income to total assets, return on assets, net NPA to net assets, and as well as on the composite financial scores of banks during the study period.

Therefore it is concluded that ownership does have bearing on the financial performance of the banking undertaking, managerial capability in any banking undertaking influences the policies and governance, which have a significant impact on the financial performance/ profitability of the bank. In the last some years stressed assets in the PSBs have increased at an alarming rate, due to politically motivated lending or due to lack of expertise in project evaluation and appraisal at the top level in these banks, which forced these banks for high provisioning and impaired their profitability. The PSBs are a major player in the Indian financial market with wide geographical coverage and huge customer base, even can be said as the backbone of the Indian financial market, hence government should ensure these banks be managed on principles of corporate best practices and a system of good governance should prevail in these public entities.

\section{REFERENCES}

[1] Bhayani, S. (2006). Performance of the New Indian Private Sector Banks: A Comparative Study. Journal of Management Research, 5(11), 53-70.

[2] Das, Abhiman (1999). Profitability of Public Sector Banks: A Decomposition Model. Reserve Bank of India Occasional Papers, 20 (1), 55-81.

[3] Divatia, V. V., \& Venkachalam, T. R. (1978). Operational Efficiency and Profitability of Public Sector Banks. RBI Occasional Papers, 3(1), 1-16. 
Ownership Does Matter in the Financial Performance of a Banking Undertaking: Evidence from the

Comparative Financial Performance of Public Sector Banks and Private Sector Banks in India

[4] Ram Mohan, T. T. (2002). Deregulation and Performance of Public Sector Banks. Economic and Political Weekly 37(5), 393-397

[5] Sangmi, M. D., \& Nazir, T. (2010). Analyzing financial performance of commercial banks in India: an application of CAMEL model. Pakistan Journal of Commerce and Social Science, $4(1), 40-55$

[6] Swami, S. B. \& Subrahmanyam, G. (1993). Comparative Performance of Public Sector Bank in India. Prajnan, 23, 185-195

[7] Verghese, S. K. (1983). Profits and Profitability of Indian Commercial Banks in Seventies. Economic and Political Weekly, 18(48) 145-157.

[8] Johri, S., \& Singh, M. (2015). Financial Assessment of Public and Private Banks in India. International Journal of Social Sciences and Management, 2(3), 228-235.

[9] Sengupta, A., \& De, S. (2020). Assessing Performance of Banks in India Fifty Years After Nationalization. India Studies in Business and Economics. 